\title{
CD2/CD21 index: A new marker to evaluate udder health in dairy cows
}

\author{
D. Schwarz, ${ }^{*}$ A. L. Rivas,†‡ S. König,§ U. S. Diesterbeck, ${ }^{*}$ K. Schlez,\# M. Zschöck,\# W. Wolter,॥ \\ and C.-P. Czerny* \\ *Department of Animal Sciences, Institute of Veterinary Medicine, Division of Microbiology and Animal Hygiene, Faculty of Agricultural Sciences, \\ Georg-August-University Göttingen, Burckhardtweg 2, 37077 Göttingen, Germany \\ †Department of Population Health and Pathobiology, College of Veterinary Medicine, North Carolina State University, Raleigh 27606 \\ $\ddagger$ Center for Global Health, School of Medicine, University of New Mexico, Albuquerque 87131 \\ §Department of Animal Breeding, University of Kassel, Nordbahnhofstraße 1a, 37213 Witzenhausen, Germany \\ \#Landesbetrieb Hessisches Landeslabor, Schubertstraße 60, 35392 Gießen, Germany \\ IRegierungspräsidium Gießen, Milk Control, Schanzenfeldstraße 8, 35578 Wetzlar, Germany
}

\section{ABSTRACT}

Lymphocytes play a significant role in the immunological processes of the bovine mammary gland and were found to be the dominant cell population in the milk of healthy udder quarters. The objective of this study was to investigate the quantitative relationship between $\mathrm{CD} 2^{+} \mathrm{T}$ and $\mathrm{CD} 21^{+} \mathrm{B}$ lymphocytes using flow cytometry. In a first study, quarter foremilk samples from apparently healthy udder quarters [somatic cell counts (SCC) $\leq 100,000$ cells $/ \mathrm{mL} ; \mathrm{n}=65$ ] were analyzed and compared with diseased quarters (SCC $>100,000$ cells $/ \mathrm{mL} ; \mathrm{n}=15)$. Percentages of $\mathrm{CD}^{+} \mathrm{T}$ cells were significantly higher in milk samples with $\mathrm{SCC} \leq 100,000$ cells $/ \mathrm{mL}$ than in those with $\mathrm{SCC}>100,000$ cells $/ \mathrm{mL}$, whereas percentages of $\mathrm{CD} 21^{+} \mathrm{B}$ cells developed in the opposite direction. As a result of this opposing trend, a new variable, the CD2/CD21 index-representing the percentages of $\mathrm{CD} 2{ }^{+}$cells per $\mathrm{CD} 21^{+}$cells - was defined. Although diseased quarters with SCC $>100,000$ cells $/ \mathrm{mL}$ and the detection of major pathogens revealed generally CD2/CD21 indices $<10$, values $>10$ were observed in apparently healthy quarters. Hence, a CD2/ CD21 index cutoff value of 10 may be suitable to aid differentiation between unsuspicious and microbiologically suspicious or diseased udder quarters. To test whether CD2/CD21 indices $<10$ were primarily related to pathogens, quarters with $\mathrm{SCC} \leq 100,000$ cells $/ \mathrm{mL}$ and $>100,000$ cells $/ \mathrm{mL}$ with different bacteriological status (culture negative, or minor or major pathogens) were selectively examined in a second biphasic study. In the first trial, 63 udder quarters were analyzed and 55 of these quarters were able to be sampled again in the second trial carried out $14 \mathrm{~d}$ later. In both trials, results of the first study were confirmed. Indeed, CD2/ CD21 indices $<10$ were also found in quarters showing

Received March 13, 2013.

Accepted May 2, 2013.

${ }^{1}$ Corresponding author: cczerny@gwdg.de
$\mathrm{SCC} \leq 100,000$ cells/mL and containing minor or major pathogens at the time of the current or previous bacteriological analysis. The results of our examinations indicated a clear relationship between the CD2/CD21 index and the bacteriological status of the mammary gland. In combination with SCC, it offers a new marker for quick differentiation of unsuspicious and microbiologically suspicious or diseased udder quarters.

Key words: mastitis, lymphocyte, flow cytometry, udder health marker

\section{INTRODUCTION}

Mastitis is a major cause of economic losses to the dairy industry in developed countries (Reneau and Packard, 1991; Seegers et al., 2003). The most common cause of mastitis is infection with udder pathogenic microorganisms. To induce mastitis, pathogens must enter the mammary gland by passing through the teat canal and overcoming the defense mechanisms of the udder (Jain, 1979). For mastitis diagnosis, traditional and well-established tests including SCC and microbial culture-based methods are standard (Viguier et al., 2009). According to current definitions of udder health in Germany, SCC $\leq 100,000$ cells/mL in quarter foremilk samples are in the physiological range (DVG, 2002).

Lymphocytes were detected in high numbers in the mammary gland tissue of ruminants as well as in milk and dry secretions (Sordillo and Nickerson, 1988; Lee et al., 1989; Schwarz et al., 2011a,b). The predominance of these cells in healthy mammary glands suggests that lymphocytes play a significant role in maintaining the integrity of the mammary gland (Shafer-Weaver et al., 1996) and in host defense against infectious diseases of the mammary gland (Sordillo et al., 1991). Data from the literature indicates that mammary gland lymphocytes are capable of a broad range of effector functions, including cytotoxic, suppressor, and antibacterial actions (Sordillo et al., 1991; Park et al., 1993). 
Studies involving monoclonal antibodies have revealed that the majority of lymphocytes in mammary gland tissues and secretions are $\mathrm{T}$ lymphocytes, with the remaining population consisting of B lymphocytes and natural killer cells (Outteridge and Lee, 1988; Lee et al., 1989). The $\mathrm{T}$ lymphocytes, including $\alpha / \beta$ (Davis and Splitter, 1991) and $\gamma / \delta$ cells (Davis et al., 1996; Asai et al., 2000; Faldyna et al., 2006), express CD2 molecules on their surface; $\alpha / \beta$ lymphocytes are made up of $\mathrm{CD}^{+}$(T-helper) and $\mathrm{CD}^{+}$(T-cytotoxic or $\mathrm{T}$ suppressor) cells (Asai et al., 1998); $\mathrm{CD}^{+}$cells are activated in response to the recognition of antigen-major histocompatibility complex (MHC) class II complexes on antigen-presenting cells, such as T lymphocytes and macrophages (Sordillo and Streicher, 2002); CD8 ${ }^{+}$cells act by eliminating host cells expressing foreign antigens in association with MHC class I molecules or they control the immune response by suppressing the activation of these cells during bacterial infection (Sordillo and Streicher, 2002; Oviedo-Boyso et al., 2007). The group of $\gamma / \delta$ lymphocytes is not as well characterized, but it has been suggested that they can be cytotoxic and may provide a unique line of defense against bacterial infections (Sordillo and Streicher, 2002). It is known that $\gamma / \delta$ lymphocytes migrate preferentially to epithelial surfaces and do not circulate extensively (Allison and Havran, 1991). On epithelial surfaces they destroy damaged epithelial cells (Sordillo and Streicher, 2002). B lymphocytes express the CD21 molecule and can serve as antigen-presenting cells. They secrete cytokines and differentiate into plasma cells that produce immunoglobulins (Sopp, 1996; Sordillo and Streicher, 2002; Oviedo-Boyso et al., 2007; Mehrzad et al., 2008). Earlier studies (Rivas et al., 2002, 2007) indicate a decrease in percentages of $\mathrm{CD}^{+}$milk $\mathrm{T}$ lymphocytes $1 \mathrm{~d}$ after the mammary glands of healthy dairy cows have been experimentally challenged with Staphylococcus aureus.

In a recent study (Pilla et al., 2012), lymphocytes were found to be the only individual cell population showing statistically varying percentages between healthy and 3 other kinds of diseased udder quarters, indicating that their percentages are susceptible to change. However, research into the qualitative role of milk leukocytes in udders classified as healthy (SCC $\leq 100,000$ cells $/ \mathrm{mL}$ ) is limited (Dosogne et al., 2003). The analysis of the relationship between immune cells (lymphocytes, macrophages, and granulocytes) in milk revealed inflammatory processes based on the predominance of granulocytes in apparently healthy mammary glands (SCC $\leq 100,000$ cells $/ \mathrm{mL}$; Schwarz et al., 2011a,b). Lymphocytes were discovered to be a dominant cell population in the milk of healthy udder quarters (Schwarz et al., 2011a,b; Pilla et al., 2012). The objective of the current study was to analyze the quantitative relationship between $\mathrm{CD} 2^{+} \mathrm{T}$ and $\mathrm{CD} 21^{+}$ B lymphocytes in quarter foremilk samples using flow cytometry to check early changes of the immunological status of the mammary gland. Therefore, predominantly udder quarters with $\mathrm{SCC} \leq 100,000$ cells $/ \mathrm{mL}$ and different bacteriological profiles (culture negative, or minor or major pathogens) were investigated, as well as quarters with SCC >100,000 cells/mL.

\section{MATERIALS AND METHODS}

\section{Farms and Animals}

Four German dairy farms (A, B, C, and D) were selected at random. In the farms, 50 to 160 dairy cows were housed in pen barns and milked twice per day in milking parlors. Milking operations were similar at all farms. After forestripping into a foremilk cup, the milkers used damp cotton tissues for udder cleaning. Teats were dipped in iodine solution after milking. In all of the dairy farms, animals were fed a TMR consisting of grass and maize silage, rape grist, and cereals. Water was available ad libitum. All farms were conventional milk producers and the average herd milk yields ranged from 8,000 to $10,000 \mathrm{~kg} / \mathrm{yr}$. The animals analyzed were kept under optimal conditions, according to national guidelines.

\section{Study Design}

Two field studies were conducted. Initially, in study 1 , the general udder health status of all lactating cows from farms $\mathrm{A}, \mathrm{B}$, and $\mathrm{C}$ was determined by analyzing the SCC and bacteriological status of quarter foremilk samples (orientating base analysis). Based on this data, 20 Holstein-Frisian cows in good condition were chosen $10 \mathrm{~d}$ later for further detailed analysis of their health status by determining the SCC, bacteriological status, differential cell counts (DCC), and percentages of $\mathrm{T}$ and B lymphocytes. Because the aim of this study was to analyze apparently healthy mammary glands with low SCC values, 64 culture-negative quarters, as well as 8 quarters containing minor pathogens with SCC $\leq 100,000$ cells $/ \mathrm{mL}$ were selected. A control group of diseased quarters with $\mathrm{SCC}>100,000$ cells $/ \mathrm{mL}$, containing minor pathogens $(\mathrm{n}=5)$ or major pathogens (n $=3)$, was also selected.

To confirm and refine the results of study 1, a second biphasic study was performed. For this reason, the udder health status of all lactating cows from dairy farm D was determined initially by analyzing the SCC and the bacteriological status of quarter foremilk samples (orientating base analysis). Based on this data, 16 Holstein-Frisian cows in good condition were chosen 18 
d later to determine the SCC, bacteriological status, $\mathrm{DCC}$, and percentages of $\mathrm{T}$ and $\mathrm{B}$ lymphocytes in trial 1. One of the 16 cows selected was a 3-quarter cow, meaning that in total, 63 udder quarters were subjected to analysis. Seventeen culture-negative quarters, 18 quarters containing minor pathogens, and in particular, 6 quarters with the detection of major pathogens were chosen in the SCC range $\leq 100,000$ cells $/ \mathrm{mL}$. The selected control group (SCC >100,000 cells/mL) consisted of 6 culture-negative quarters, 7 quarters containing minor pathogens, and 9 quarters containing major pathogens. To evaluate the dynamics and repeatability of the results obtained from the base analysis and trial 1 (especially in quarters with $\mathrm{SCC} \leq 100,000$ cells $/ \mathrm{mL}$ containing major pathogens), the SCC, bacteriological status, DCC, and percentages of $\mathrm{T}$ and $\mathrm{B}$ lymphocytes of all selected cows were determined again $14 \mathrm{~d}$ later in trial 2. Samples of 2 cows could not be taken due to dry periods ( $\mathrm{n}=55$ udder quarters). In both studies, clinical mastitis symptoms, such as flecks in the milk, swelling, or redness of the udder quarters, were only observed in quarters with $\mathrm{SCC}>100,000$ cells $/ \mathrm{mL}$.

\section{Milk Sampling and Processing}

Quarter foremilk samples were obtained in accordance with German Veterinary Society (DVG, 2000) standards. Before milking, teat ends were scrubbed with $70 \%$ ethanol and the first 2 squirts of milk were discarded. Aliquots of $110 \mathrm{~mL}$ of milk per udder quarter were collected aseptically in sterile $14-\mathrm{mL}$ plastic tubes and 2 sterile 50-mL plastic tubes (Sarstedt AG \& Co., Nümbrecht, Germany). Ten milliliters was used for SCC and bacteriological examinations according to International Dairy Federation standards (IDF, 1981). Aliquots of $100 \mathrm{~mL}$ were necessary for the analysis of DCC and T and B lymphocytes. Cells were isolated from the milk using 2 centrifugation steps at $200 \times g$ for 15 min at $4^{\circ} \mathrm{C}$. Pellets were washed and resuspended in PBS to a final dilution of $1 \times 10^{6}$ cells $/ 100 \mu \mathrm{L}$, based on the predetermined SCC values for each milk sample.

\section{Flow Cytometry Analysis}

The determination of DCC has been described in detail elsewhere (Schwarz et al., 2011b). Percentages of $\mathrm{T}$ and $\mathrm{B}$ lymphocytes were also established according to that method (Schwarz et al., 2011b). Briefly, 100$\mu \mathrm{L}$ aliquots of the cell suspension were transferred into a 5-mL BD Falcon tube (BD, Heidelberg, Germany). Five-microliter volumes of the unconjugated primary monoclonal antibodies anti-CD2 (isotype: IgG2a) and anti-CD21 (isotype: IgM; 16-1E10 and BAQ15A; VMRD Inc., Pullman, WA), both diluted 1:10 in PBS, were added before the tubes were incubated on ice for $30 \mathrm{~min}$. Cells were centrifuged $(250 \times g$ for $5 \mathrm{~min}$ at $4^{\circ} \mathrm{C}$ ), resuspended in $3 \mathrm{~mL}$ of $\mathrm{PBS}$, and allowed to stand for $5 \mathrm{~min}$. After a second washing step, cells were resuspended in $50 \mu \mathrm{L}$ of PBS and incubated with secondary monoclonal antibodies. Specifically, $2.5 \mu \mathrm{L}$ of phycoerythrin-conjugated rat-anti-mouse IgM (553409; $\mathrm{BD})$ and $10 \mu \mathrm{L}$ of a mix preincubated for 30 min were applied. This mix contained $5 \mu \mathrm{L}$ of biotin-conjugated rat-anti-mouse IgG2a (553388; BD) and $5 \mu \mathrm{L}$ of PerCPCy 5.5 streptavidin (551419; BD) — both diluted 1:10 in PBS; PerCP-Cy 5.5 streptavidin was used to visualize the biotin-labeled antibody. Following incubation for $30 \mathrm{~min}$, cells were washed twice again and finally resuspended in $500 \mu \mathrm{L}$ of PBS. Cells were kept on ice during all the procedures, centrifuged at $250 \times g$ for 5 min at $4^{\circ} \mathrm{C}$, and stored in the dark.

Stained samples were analyzed using a FACSCalibur flow cytometer (BD); CellQuest Pro software (BD) was used for data collection and analysis. Five thousand events were evaluated from each sample (Schwarz et al., 2011b). Lymphocytes were identified by their size and granularity characteristics in an analysis gate, according to previous studies (Riollet et al., 2001; Rivas et al., 2001; Schwarz et al., 2011b). The CD2 ${ }^{+}$T lymphocytes and $\mathrm{CD} 21^{+} \mathrm{B}$ lymphocytes were measured simultaneously as percentages of all lymphocytes. Gates enclosing the antibody-positive cells were placed outside the upper limit of background fluorescence. Cells without antibody labeling served as a negative control and were regarded to be a measure for background fluorescence. In addition, isotype control antibodies (rat-IgG1, $\kappa$ isotype control, 553923 and rat-IgG2a, $\kappa$ isotype control, 553930; BD) were used to facilitate the measurement of background staining.

\section{Statistical Analysis}

Associations between lymphocytes, $\mathrm{CD} 2^{+} \mathrm{T}$ and CD21 ${ }^{+}$B lymphocytes, as well as between the CD2/ CD21 index (representing the percentages of CD2 ${ }^{+}$cells per $\mathrm{CD} 21^{+}$cells) and SCC were analyzed by applying linear mixed models using the SAS program (version 9.1; SAS Institute Inc., Cary, NC) according to Schwarz et al. (2011a,b). The statistical model included the random effect of the cow and the fixed effects of the farm, lactation number, position of the udder quarter, DIM, as well as the 4 SCC groups (group I: $\leq 6,250$ cells/mL; group II: $>6,250$ to $\leq 25,000$ cells $/ \mathrm{mL}$; group III: $>25,000$ to $\leq 100,000$ cells/mL; group IV: $>100,000$ cells $/ \mathrm{mL}$ ) defined in a previous study (Schwarz et al., 2010). In a further analysis, the bacteriological status was included and each of the 4 SCC groups were subdivided into culture negative $(-0)$, minor pathogens 
Table 1. General overview of SCC, percentages of lymphocyte subpopulations, and CD2/CD21 index of the quarter foremilk samples analyzed by flow cytometry

\begin{tabular}{|c|c|c|c|c|}
\hline \multirow[b]{2}{*}{ Item } & \multirow[b]{2}{*}{$\begin{array}{l}\mathrm{SCC}(\times 1,000 \\
\text { cells } / \mathrm{mL})\end{array}$} & \multicolumn{2}{|c|}{ Lymphocyte subpopulation (\%) } & \multirow[b]{2}{*}{$\begin{array}{c}\mathrm{CD} 2 / \mathrm{CD} 21 \\
\text { index }^{2}\end{array}$} \\
\hline & & CD2 & CD21 & \\
\hline \multicolumn{5}{|c|}{ Study 1 ( $\mathrm{n}=80)$} \\
\hline Mean & 86 & 52 & 2 & 63 \\
\hline SD & 233 & 22 & 1 & 64 \\
\hline Median & 38 & 52 & 1 & 43 \\
\hline Minimum & 2 & 4 & 0.05 & 0.74 \\
\hline Maximum & 1,394 & 93 & 7 & 366 \\
\hline \multicolumn{5}{|c|}{ Study $2($ trial $1, \mathrm{n}=63)$} \\
\hline Mean & 589 & 62 & 15 & 16 \\
\hline SD & 1,925 & 24 & 18 & 12 \\
\hline Median & 105 & 75 & 8 & 8 \\
\hline Minimum & 1 & 5 & 0.55 & 0.07 \\
\hline Maximum & 10,927 & 96 & 45 & 49 \\
\hline \multicolumn{5}{|c|}{ Study $2($ trial $2, \mathrm{n}=55)$} \\
\hline Mean & 329 & 72 & 10 & 15 \\
\hline SD & 760 & 18 & 9 & 15 \\
\hline Median & 36 & 75 & 6 & 12 \\
\hline Minimum & 3 & 18 & 1 & 1 \\
\hline Maximum & 4,300 & 98 & 40 & 89 \\
\hline
\end{tabular}

${ }^{1}$ All calculations are based on the individual values for each udder quarter.

${ }^{2}$ The reported CD2/CD21 index (the proportion of CD2 $2^{+}$lymphocytes per CD21 $1^{+}$lymphocytes) is not equal to the division of the reported CD2 over the reported CD21 values.

$(-1)$, and major pathogens $(-2)$ according to Reneau (1986).

\section{RESULTS}

\section{Study 1}

SCC and Bacteriological Status of Quarter Foremilk Samples. The initial cytobacteriological status in 3 German dairy herds (A, B, and C) was determined in an orientating base analysis. Variations of SCC and the bacteriological status caused moderate deviations from initial selection criteria, so that $10 \mathrm{~d}$ later, the 80 quarters selected from 20 cows showed a mean SCC value of 86,000 cells $/ \mathrm{mL}$, with a standard deviation of 233,000 cells $/ \mathrm{mL}$ (Table 1 ). In 11 of the 65 quarters with SCC $\leq 100,000$ cells $/ \mathrm{mL}$, CNS were found, but no major pathogens. Thirteen of the 15 quarters with SCC $>100,000$ cells $/ \mathrm{mL}$ were culture positive, whereas 2 were culture negative. In 5 samples (SCC 104,000 to 624,000 cells $/ \mathrm{mL}$ ), CNS were detected, and 3 samples (SCC 116,000 to 587,000 cells/mL) tested positive for Corynebacterium spp. Major pathogens were found solely in 5 quarters. Staphylococcus aureus was isolated in one of them, with an SCC value of 454,000 cells $/ \mathrm{mL}$. In 3 quarters (SCC 181,000, 1,306,000, and 1,394,000 cells/mL), Streptococcus uberis was detected, of which 2 quarters $(\mathrm{SCC}>1,000,000$ cells $/ \mathrm{mL}$ ) revealed clinical mastitis symptoms. A double infection with Strep. uberis and Streptococcus dysgalactiae was diagnosed in an udder quarter with 139,000 cells/mL.
Lymphocyte Subpopulations of Quarter Foremilk Samples. The total number of lymphocytes in the 80 quarter foremilk samples was determined by flow cytometry based on physical parameters (Riollet et al., 2001; Rivas et al., 2001; Schwarz et al., 2011b). The $\mathrm{CD}^{+} \mathrm{T}$ and $\mathrm{CD} 21^{+} \mathrm{B}$ cells were measured as percentages of all lymphocytes. Lymphocyte counts ranged between 118 to 4,393 cells per 5,000 events (mean: 2,247 cells; SD: 1,088 cells). Proportions of $\mathrm{CD} 2^{+} \mathrm{T}$ lymphocytes lay in a wide range between 4 and $93 \%$ (Table 1). The variation of CD21 ${ }^{+} \mathrm{B}$ lymphocytes was narrower, ranging from 0.05 to $7 \%$ (Table 1 ).

Wide variations were found within the total number of lymphocytes and within the proportions of $\mathrm{T}$ lymphocytes. Total numbers of lymphocytes were higher in milk with SCC $\leq 100,000$ cells $/ \mathrm{mL}$ than in milk with SCC $>100,000$ cells $/ \mathrm{mL}$ (Figure 1a). The percentages of $\mathrm{CD}^{+}$cells in milk samples with $\mathrm{SCC} \leq 100,000$ cells/ $\mathrm{mL}$ were considerably higher than in samples with SCC $>100,000$ cells $/ \mathrm{mL}$ (Figure 1b). The profile of CD21 ${ }^{+}$ cells was the opposite (Figure 1c).

The statistical analysis indicated a significant $(P<$ $0.001)$ negative correlation between the total number of lymphocytes and SCC ( $\mathrm{r}=-0.40)$, as well as between the percentages of $\mathrm{CD}^{+}$lymphocytes and $\mathrm{SCC}$ $(\mathrm{r}=-0.52$; Table 2). In contrast, the correlation between the percentages of $\mathrm{CD} 21^{+}$cells and SCC was evidently $(P<0.001)$ positive $(\mathrm{r}=0.25)$. The farm had a considerable $(P<0.05)$ effect on the total number of lymphocytes, as well as on the percentages of 
A

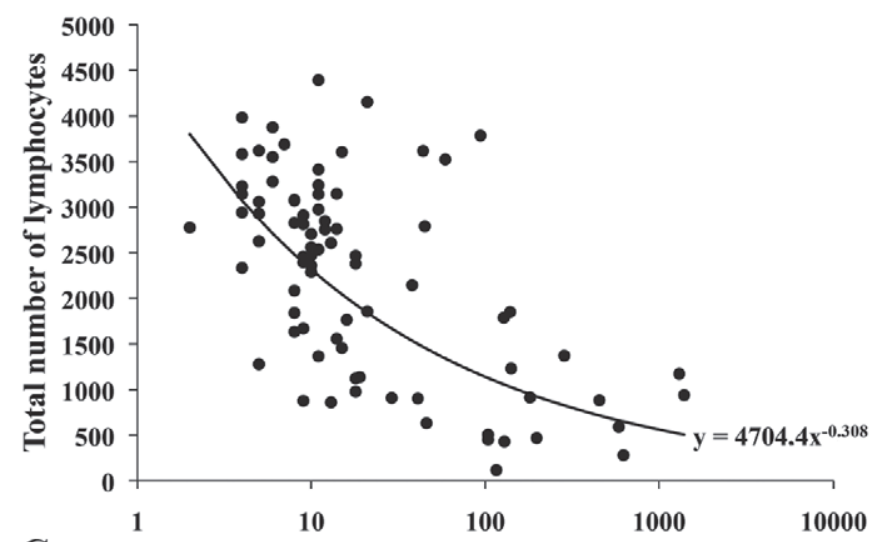

C

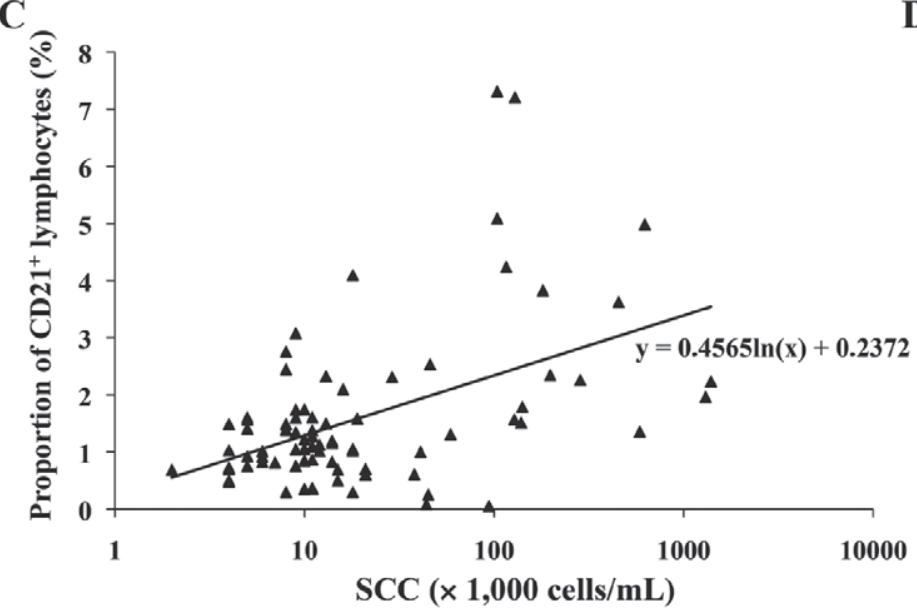

B
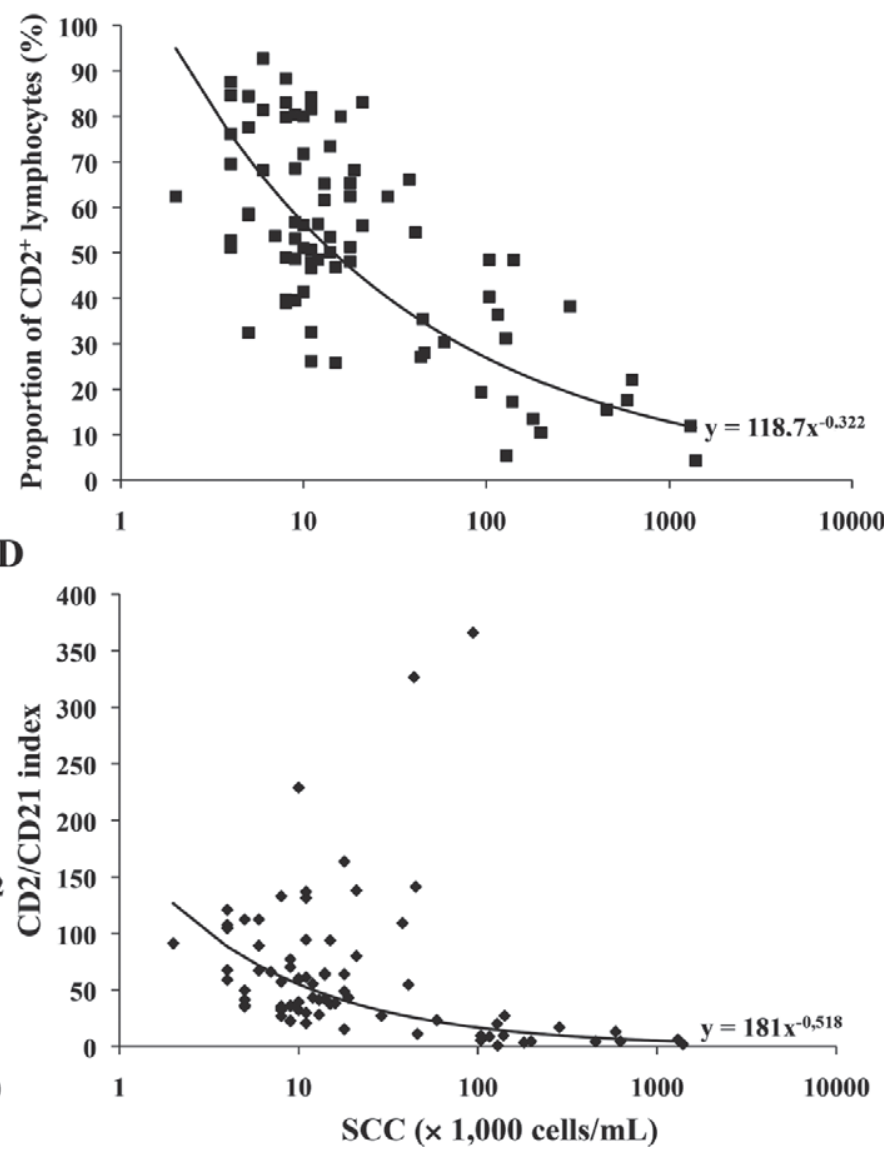

Figure 1. Lymphocyte subpopulations of 80 udder quarters (study 1) depending on the SCC. The total number of cells/mL (SCC) was determined for each quarter foremilk sample. Cells were then isolated and analyzed by flow cytometry: (A) total number of lymphocytes (filled circles); (B) proportions of CD2 ${ }^{+}$lymphocytes (filled squares); (C) proportions of CD21 lymphocytes (filled triangles). (D) Values of the proportion of $\mathrm{CD} 2^{+}$lymphocytes per CD21 $1^{+}$lymphocytes (CD2/CD21 index; filled diamonds). Data are illustrated in combination with a calculated potential (A, B, and D) or logarithmic (C) trend line. Each symbol represents the result of 1 udder quarter analyzed, but overlapping is possible.

$\mathrm{CD}^{+}$lymphocytes. The total number of lymphocytes was further influenced significantly $(P<0.05)$ by the lactation number, but not by DIM or the position of the udder quarter. Percentages of $\mathrm{CD}^{+}$and $\mathrm{CD} 21^{+}$ lymphocytes were affected by none of these parameters.

Determination of the CD2/CD21 Index. As indicated by the calculated trend lines, percentages of $\mathrm{CD}_{2}^{+}$and $\mathrm{CD}_{2} 1^{+}$cells emerged in contrary directions as SCC increased (Figures $1 \mathrm{~b}$ and 1c). Due to this opposing trend, a new variable - the CD2/CD21 index - was defined. It represents the ratio between the percentages of $\mathrm{CD} 2^{+}$cells per $\mathrm{CD} 21^{+}$cells and was calculated for each udder quarter. In the 80 quarter foremilk samples analyzed, this indicator showed values in a wide range from 0.74 to 366 (Table 1). The CD2/ CD21 index was considerably higher in milk samples with $\mathrm{SCC} \leq 100,000$ cells $/ \mathrm{mL}$ than in samples with SCC $>100,000$ cells/mL (Figure 1d). The statistical analysis indicated no influence of the farm, position of the udder quarter, number of lactation, or DIM (Table 2 ). However, the correlation between the CD2/CD21 index and SCC was significantly $(P<0.001)$ negative $(\mathrm{r}=-0.25$; Table 2$)$, meaning that particularly high SCC quarters containing pathogens, which are generally considered to be linked to mastitis, were associated with low CD2/CD21 indices.

Evaluation of the CD2/CD21 Index Depending on the Udder Health Status. For an improved differentiation of healthy and latent infected udder quarters $(\leq 100,000$ cells $/ \mathrm{mL})$, the 80 samples were classified into 4 SCC groups (group I: $\leq 6,250$ cells $/ \mathrm{mL}$, group II: $>6,250$ to $\leq 25,000$ cells $/ \mathrm{mL}$, group III: $>25,000$ to $\leq 100,000$ cells $/ \mathrm{mL}$, and group IV: $>100,000$ cells $/ \mathrm{mL}$ ), as defined in a previous study (Schwarz et al., 2010). The bacteriological status was considered additionally by subdividing each SCC group into culture negative $(-0)$, minor pathogens $(-1)$, or major pathogens $(-2)$ according to Reneau (1986; Figure 2). 
Table 2. Variance analysis ${ }^{1}$ of the total number of lymphocytes, percentages of CD2 ${ }^{+}$and $\mathrm{CD} 21^{+}$lymphocytes, and CD2/CD21 index (the proportion of CD2 ${ }^{+}$lymphocytes per CD21 $1^{+}$lymphocytes)

\begin{tabular}{|c|c|c|c|c|c|}
\hline \multirow[b]{2}{*}{ Item } & \multicolumn{5}{|c|}{ Effect ( $P$-value $)$} \\
\hline & $\mathrm{SCC}$ & $\begin{array}{l}\text { Quarter } \\
\text { position }\end{array}$ & $\begin{array}{c}\text { Lactation } \\
\text { number }\end{array}$ & DIM & Farm \\
\hline \multicolumn{6}{|l|}{ Study $1(\mathrm{n}=80)$} \\
\hline Lymphocytes & 0.0001 & 0.62 & 0.04 & 0.44 & 0.05 \\
\hline $\mathrm{CD}^{+}$lymphocytes & 0.0001 & 0.62 & 0.70 & 0.79 & 0.0002 \\
\hline $\mathrm{CD} 21^{+}$lymphocytes & 0.0001 & 0.82 & 0.10 & 0.36 & 0.22 \\
\hline CD2/CD21 index & 0.0001 & 0.52 & 0.07 & 0.53 & 0.19 \\
\hline \multicolumn{6}{|l|}{ Study $2($ trial $1, \mathrm{n}=63)$} \\
\hline Lymphocytes & 0.0001 & 0.44 & 0.72 & 0.07 & - \\
\hline $\mathrm{CD}^{+}$lymphocytes & 0.29 & 0.37 & 0.96 & 0.72 & - \\
\hline CD21 $1^{+}$lymphocytes & 0.02 & 0.91 & 0.26 & 0.12 & - \\
\hline CD2/CD21 index & 0.0005 & 0.56 & 0.37 & 0.22 & - \\
\hline \multicolumn{6}{|l|}{ Study $2($ trial $2, \mathrm{n}=55)$} \\
\hline Lymphocytes & 0.0001 & 0.69 & 0.59 & 0.56 & - \\
\hline $\mathrm{CD} 2^{+}$lymphocytes & 0.30 & 0.22 & 0.97 & 0.50 & - \\
\hline $\mathrm{CD} 21^{+}$lymphocytes & 0.0001 & 0.73 & 0.58 & 0.72 & - \\
\hline CD2/CD21 index & 0.02 & 0.16 & 0.90 & 0.64 & - \\
\hline
\end{tabular}

${ }^{1}$ Analyzed factors were the SCC, quarter positions (front right, rear right, front left, and rear left), lactation number (1, 2, and $\geq 3$ ), DIM (61-99 d, 102-175 d, and 246-360 d), and farm (A, B, and C).

In culture-negative quarters with $\mathrm{SCC} \leq 100,000$ cells $/ \mathrm{mL}(\mathrm{I}-0: \mathrm{n}=11 ; \mathrm{II}-0: \mathrm{n}=33 ;$ III- $0: \mathrm{n}=7)$, the CD2/CD21 index varied greatly between 11.06 and 366 . Samples within this SCC category containing minor pathogens (I-1: $\mathrm{n}=4$; II-1: $\mathrm{n}=6$; III- $1: \mathrm{n}=1$ ) showed CD2/CD21 indices in a much narrower range: from 20.58 to 104.83 . In the SCC category $>100,000$ cells/ $\mathrm{mL}(\mathrm{IV}-0: \mathrm{n}=2 ; \mathrm{IV}-1: \mathrm{n}=8 ; \mathrm{IV}-2: \mathrm{n}=5), \mathrm{CD} 2 / \mathrm{CD} 21$ indices revealed markedly lower values in a closer range from 0.74 to 27.09 . Whereas 11 of 15 quarters with SCC $>100,000$ cells $/ \mathrm{mL}$ indicated values $<10$, values $>10$ were found in 4 quarters [IV-0 $(\mathrm{n}=1): 27.09$; IV-1 $(\mathrm{n}=3): 13.00-19.93)$. The CD2/CD21 index of samples in group IV-2 was generally $<10(1.90-9.59)$.

The statistical analysis indicated notably $(P<0.05)$ lower mean values of the CD2/CD21 index in groups I-0 (76) and II-0 (90) compared with group III-0 (146). Furthermore, the mean values in groups I-0, II-0, III0 , and I-1 $(149)$ were considerably $(P<0.05)$ higher than in groups IV-0 (0.54), IV-1 (24), and IV-2 (9). However, the mean CD2/CD21 indices in groups II-1 (78) and III-1 (87) did not differ significantly from any of the other groups. The major finding of study $1 \mathrm{dem}-$ onstrated that CD2/CD21 indices were generally $>10$ in quarters with $\mathrm{SCC} \leq 100,000$ cells $/ \mathrm{mL}$, independent of the detection of minor pathogens, whereas almost all samples with $\mathrm{SCC}>100,000$ cells $/ \mathrm{mL}$, containing minor or major pathogens, indicated values $<10$.

\section{Study 2}

SCC, Lymphocyte Subpopulations, and CD2/ CD21 Index. To investigate whether a CD2/CD21 index of $<10$ was primarily related to minor or major pathogens, a second independent study with 2 trials was conducted in farm D. Cows were selected in an orientating base analysis with respect to $\mathrm{SCC}(\leq$ or $>100,000$ cells $/ \mathrm{mL}$ ) and bacteriological status (either culture negative or containing minor/major pathogens). As in study 1, variations of SCC and the bacteriological status caused moderate deviations from initial selection criteria (Table 3 ). To evaluate the dynamics and repeatability of the results, 2 trials were performed within a 14-d period.

In trial 1, which used 63 quarters of 16 cows, the mean SCC value of 589,000 cells $/ \mathrm{mL}$ (Table 1) was higher than in study 1 , and caused by the examination of 5 clinically diseased quarters with SCC values between 1,054,000 and 10,927,000 cells/mL. In trial 2 , the SCC mean value decreased to 329,000 cells $/ \mathrm{mL}$ (Table 1 ), as values of the 5 clinically diseased quarters decreased to 848,000 and $4,300,000$ cells $/ \mathrm{mL}$, respectively. As in study 1 , lymphocyte counts were detected in a wide range in trial 1 (99 to 4,556 cells; mean value: 1,397; SD: 996) and trial 2 (119 to 4,556 cells; mean value: 1,628 ; SD: 1,066). The proportions of $\mathrm{CD}^{+} \mathrm{T}$ lymphocytes also lay in a wide range (Table 1; trial 1 : 5-96\%; trial 2: 18-98\%), whereas proportions of CD21 ${ }^{+}$ B lymphocytes were clearly higher than those found in study 1 (trial 1: $0.55-45 \%$; trial 2: 1-40\%). The results of variance analysis of data from trials 1 and 2 were similar to those obtained from study 1 , with the exception that lymphocytes were not significantly influenced by lactation number and percentages of $\mathrm{CD} 2^{+}$cells did not correlate significantly with SCC (Table 2).

Evaluation of CD2/CD21 Index Depending on Pathogens. The CD2/CD21 index lay in a range from 0.07 to 49 in trial 1 and from 1 to 89 in trial 2 (Table 1 ) 


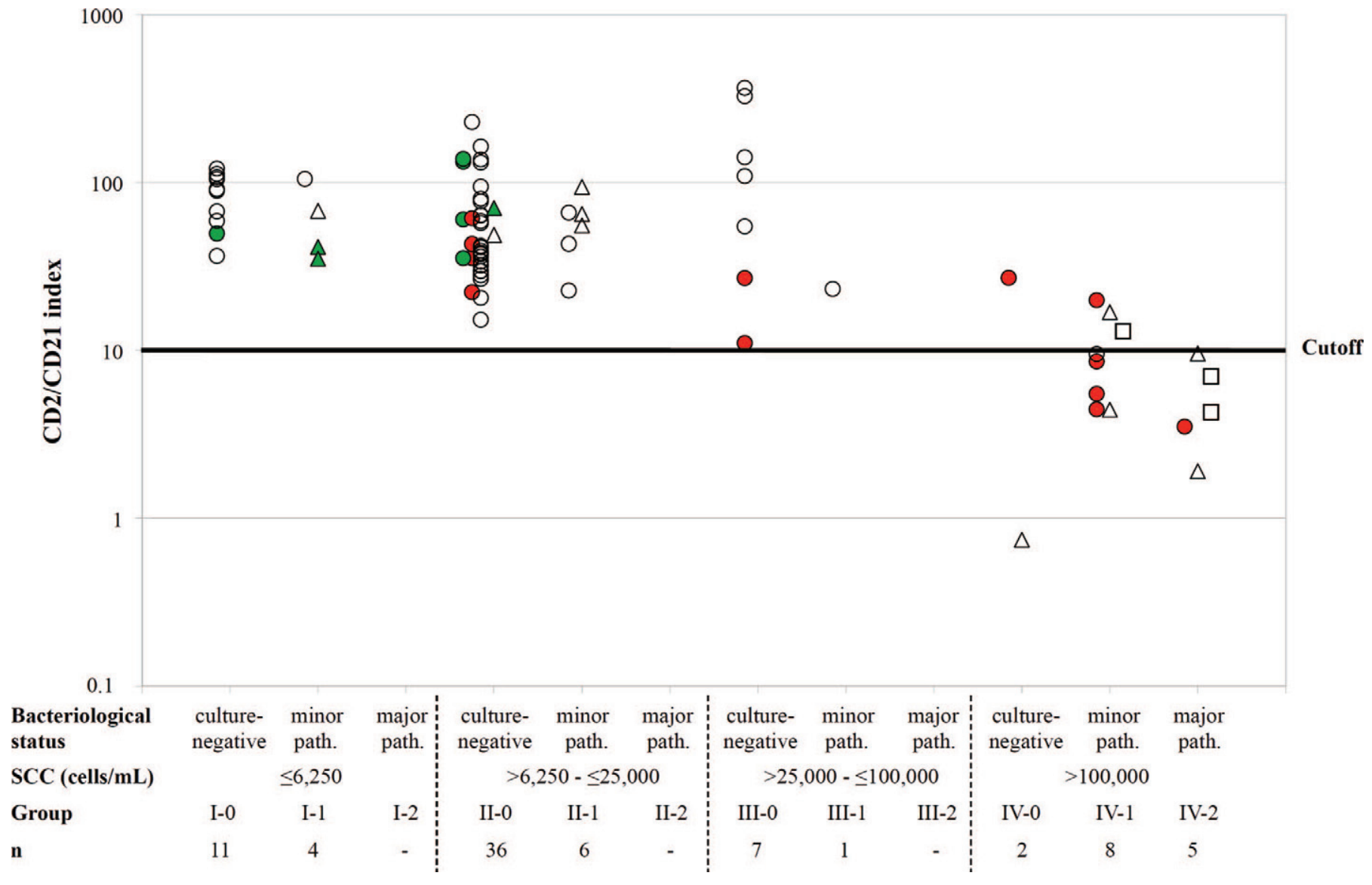

Figure 2. Associations between the proportion of CD2 ${ }^{+}$lymphocytes per CD21 lymphocytes (CD2/CD21 index) and cytobacteriological status of the 80 quarter foremilk samples in study 1 . The samples were classified into 4 SCC groups (group I: $\leq 6,250$ cells/mL; group II: $>6,250$ to $\leq 25,000$ cells $/ \mathrm{mL}$; group III: $>25,000$ to $\leq 100,000$ cells $/ \mathrm{mL}$; group IV: $>100,000$ cells/mL). Each group was subdivided additionally into culture negative $(-0)$, minor pathogens $(-1)$, and major pathogens $(-2)$. To show the dynamics of the udder health status, the cytobacteriological status at the orientating base analysis is indicated for each quarter by the following symbols: $\bigcirc=$ negative, $\Delta=$ minor pathogens, and $\square=$ major pathogens. White = same SCC group at orientating base analysis and major analysis; green (light gray) = SCC was at least 1 SCC group higher at orientating base analysis; red (dark gray) = SCC was at least 1 SCC group lower at orientating base analysis. Each symbol represents the result of 1 udder quarter analyzed, but overlapping is possible. path. = pathogens. Color version available in the online PDF.

indicating that the minimum values were in the same range compared with study 1 , but maximum values were clearly lower. As in study 1 , study 2 revealed a significant negative correlation between the CD2/CD21 index and SCC (trial 1: $\mathrm{r}=-0.22$; trial 2: $\mathrm{r}=-0.20$; Table 2).

In the SCC category $\leq 100,000$ cells $/ \mathrm{mL}$ of trial 1 , 9 of 31 quarters from groups I-0 $(\mathrm{n}=1 / 7), \mathrm{I}-1 \quad(\mathrm{n}=$ $1 / 10)$, II-0 ( $\mathrm{n}=3 / 7)$, II-1 $(\mathrm{n}=2 / 3)$, III-1 $(\mathrm{n}=1 / 2)$, and III-2 $(\mathrm{n}=1 / 1)$ indicated CD2/CD21 indices of $<10$ (2.22-9.64; Figure 3 and Table 3). With the exception of quarter no. 7 (CD2/CD21 index 8.69), minor or major pathogens could be detected either at the current (trial 1) or former (base analysis) bacteriological investigation in 8 of these 9 quarters. In 4 of these quarters (I-0: no. 1; I-1: no. 2; II-0: no. 4; III-2: no. 3), with CD2/CD21 indices ranging between 2.22 and 9.64,
Staph. aureus was detected at the base analysis (Figure 3). In another 4 quarters (II-0: no. 12; II-1: no. 8 and 9; III-1: no. 10) with CD2/CD21 indices of 6.44 to 8.28, a recent or former relationship to minor pathogens was detected.

In the category $>100,000$ cells $/ \mathrm{mL}, 28$ of 32 samples from groups IV-0 $(\mathrm{n}=1 / 4), \mathrm{IV}-1 \quad(\mathrm{n}=16 / 17)$, and $\mathrm{IV}-2(\mathrm{n}=11 / 11)$ clustered in a CD2/CD21 index range $<10(0.07-8.30)$. With the exception of no. 11 (CD2/ CD21 index 5.21), all of these quarters showed a current or partly former connection to minor or major pathogens (Figure 3 and Table 3). In group IV-2, only major pathogens such as Staph. aureus, Strep. uberis, and Strep. dysgalactiae were isolated.

Statistical analysis revealed significantly $(P<0.05)$ higher mean values of the CD2/CD21 index in groups I-0 (14), II-0 (16), III-0 (22), and I-1 (19) compared 
Table 3. Overview of the SCC, bacteriological status, and CD2/CD21 index (the proportion of CD2 $2^{+}$lymphocytes per CD21 lymphocytes) of 18 selected udder quarters from study 2 at the base analysis, in trials 1 and $2^{1}$

\begin{tabular}{|c|c|c|c|c|c|c|c|c|c|c|}
\hline \multirow[b]{2}{*}{ No. } & \multirow[b]{2}{*}{ Cow } & \multirow[b]{2}{*}{$\begin{array}{l}\text { Quarter } \\
\text { position }^{2}\end{array}$} & \multicolumn{2}{|c|}{ Orientating base analysis ${ }^{3}$} & \multicolumn{3}{|c|}{ Trial 1} & \multicolumn{3}{|c|}{ Trial 2} \\
\hline & & & $\begin{array}{c}\text { SCC } \\
(\times 1,000 \\
\text { cells } / m L)\end{array}$ & $\begin{array}{l}\text { Bacteriological } \\
\text { status }\end{array}$ & $\begin{array}{c}\mathrm{SCC} \\
(\times 1,000 \\
\text { cells } / \mathrm{mL})\end{array}$ & $\begin{array}{l}\text { Bacteriological } \\
\text { status }\end{array}$ & $\begin{array}{l}\text { CD2/CD21 } \\
\text { index }\end{array}$ & $\begin{array}{c}\mathrm{SCC} \\
(\times 1,000 \\
\text { cells } / \mathrm{mL})\end{array}$ & $\begin{array}{l}\text { Bacteriological } \\
\text { status }\end{array}$ & $\begin{array}{l}\text { CD2/CD21 } \\
\text { index }\end{array}$ \\
\hline 1 & 401 & $\mathrm{RR}$ & 11 & Staphylococcus aureus & 6 & Negative $^{4}$ & 8.69 & 62 & Negative & 1.46 \\
\hline 2 & 401 & RL & 11 & Staph. aureus & 3 & $\mathrm{CNS}$ & 2.22 & 12 & Negative & 21.61 \\
\hline 3 & 345 & $\mathrm{RR}$ & 23 & Staph. aureus & 53 & Staph. aureus & 9.64 & 36 & Staph. aureus & 6.43 \\
\hline 4 & 345 & $\mathrm{FL}$ & 13 & Staph. aureus & 16 & Negative & 5.64 & 34 & Corynebacterium spp. & 1.44 \\
\hline 5 & 390 & $\mathrm{RR}$ & 5 & Staph. aureus & 4 & CNS & 12.16 & 5 & Negative & 10.20 \\
\hline 6 & 445 & $\mathrm{RR}$ & 34 & Staph. aureus & 127 & Negative & 28.17 & 68 & Negative & 19.67 \\
\hline 7 & 387 & $\mathrm{FL}$ & 25 & Negative & 10 & Negative & 8.69 & 7 & Corynebacterium spp. & 37.65 \\
\hline 8 & 387 & $\mathrm{RR}$ & 11 & CNS & 8 & Corynebacterium spp. & 8.28 & 7 & Negative & 32.26 \\
\hline 9 & 345 & $\mathrm{RL}$ & 10 & CNS & 13 & CNS & 6.58 & 10 & Negative & 8.77 \\
\hline 10 & 345 & $\mathrm{FR}$ & 11 & Negative & 42 & CNS & 6.44 & 19 & CNS & 18.39 \\
\hline 11 & 278 & FL & 192 & Negative & 1,596 & Negative & 5.21 & 4,300 & CNS & 7.87 \\
\hline 12 & 320 & FR & 2 & CNS & 9 & Negative & 8.86 & 32 & Negative & 16.58 \\
\hline 13 & 223 & $\mathrm{RL}$ & 4 & CNS & 3 & Negative & 13.21 & 4 & Negative & 6.63 \\
\hline 14 & 278 & FR & 185 & Negative & 133 & Corynebacterium spp. & 8.30 & 233 & Negative & 3.87 \\
\hline 15 & 278 & $\mathrm{RR}$ & 109 & Negative & 138 & CNS & 3.73 & 155 & Negative & 4.40 \\
\hline 16 & 323 & $\mathrm{FL}$ & 118 & Corynebacterium spp. & 588 & Corynebacterium spp. & 3.02 & 705 & Negative & 6.52 \\
\hline 17 & 328 & RL & 127 & Corynebacterium spp. & 144 & Corynebacterium spp. & 13.34 & 132 & Negative & 4.84 \\
\hline 18 & 393 & $\mathrm{RR}$ & 57 & CNS & 68 & CNS & 15.01 & 45 & CNS & 8.36 \\
\hline
\end{tabular}

Or diseased querters 18 were selected bect

을 $\quad{ }^{4}$ Negative $=$ no cultural growth of microorganisms. 


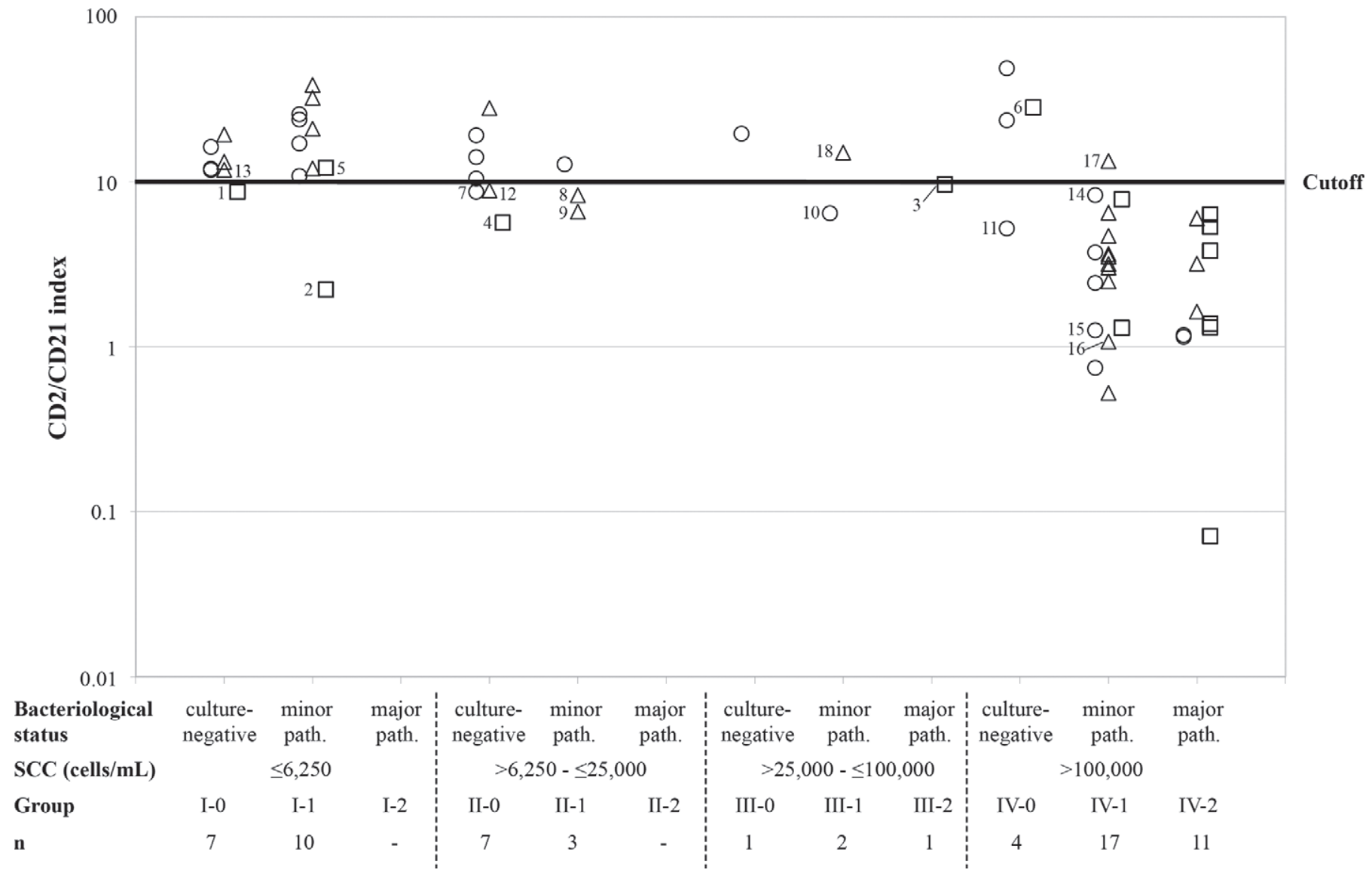

Figure 3. Associations between the proportion of CD2 ${ }^{+}$lymphocytes per CD21 lymphocytes (CD2/CD21 index) and cytobacteriological status of the 63 udder quarters in trial 1. The samples were classified into 4 SCC groups (group I: $\leq 6,250$ cells/mL; group II: $>6,250$ to $\leq 25,000$ cells/mL; group III: $>25,000$ to $\leq 100,000$ cells/mL; group IV: $>100,000$ cells/mL). Each group was subdivided into culture negative $(-0)$, minor pathogens $(-1)$, and major pathogens $(-2)$. To show the dynamics of the udder health status, the cytobacteriological status at the orientating base analysis is indicated for each quarter by the following symbols: $\bigcirc=$ negative, $\Delta=$ minor pathogens, and $\square=$ major pathogens. Quarter numbers 1 to 18 are marked for additional analysis of differential cell counts, as their CD2/CD21 index differed from our working hypothesis ( $>10$ in unsuspicious quarters and $<10$ in microbiologically suspicious or diseased quarters) either in trial 1 or 2 . Each symbol represents the result of 1 udder quarter analyzed, but overlapping is possible. path. $=$ pathogens.

with group IV-1 (4). Furthermore, the mean values in groups II-0 and IV-0 $(20)$ were notably $(P<0.05)$ higher than in group IV-2 (6). However, the mean CD2/CD21 indices in groups II-1 (13), III-1 (14), and III-2 (14) did not differ significantly from any of the other groups.

Moreover, study 2 indicated so far that in almost all quarters with SCC >100,000 cells/mL, CD2/CD21 indices were clearly lower than in those with SCC $\leq 100,000$ cells $/ \mathrm{mL}$. However, because values $<10$ were sporadically found in samples of groups I-0, I-1, II-0, II-1, III-1, and III-2, trial 2 was conducted $14 \mathrm{~d}$ later to verify the threshold of 10 . Due to dry periods, only 14 ( $\mathrm{n}=55$ udder quarters) of 16 cows could be sampled and analyzed again.

In trial 2, all udder quarters with CD2/CD21 indices $<10(\mathrm{n}=24)$ offered a current or former history with positive bacteriological results (Figure 4). In the SCC range $\leq 6,250$ to $\leq 25,000$ cells $/ \mathrm{mL}$, only 2 quarters (I0: $\mathrm{n}=1 / 8$; II-0: $\mathrm{n}=1 / 7$ ) with CD2/CD21 indices $<10$ were found. A slight increase was seen in the SCC range $>25,000$ to $\leq 100,000$ cells $/ \mathrm{mL}$, where 4 quarters (III-0: $\mathrm{n}=1 / 6$; III- $1: \mathrm{n}=2 / 4$; III- $2: \mathrm{n}=1 / 1$ ) revealed values $<10$. In the SCC range $>100,000$ cells $/ \mathrm{mL}, 18$ of 22 quarters (IV-0: $\mathrm{n}=4 / 5$; IV-1: $\mathrm{n}=8 / 11 ; \mathrm{IV}-2$ : $\mathrm{n}=6 / 6)$ indicated values $<10$. Three of the 4 udder quarters within this category with CD2/CD21 indices of $>10$ (IV-1: 10.87-12.63) were closely related to the threshold. The CD2/CD21 index was $<10$ again in all quarters of group IV-2, where the major pathogens Staph. aureus, Strep. uberis, and Strep. dysgalactiae were isolated.

Statistical analysis revealed a considerably $(P<$ 0.05) higher mean value of the CD2/CD21 index in 


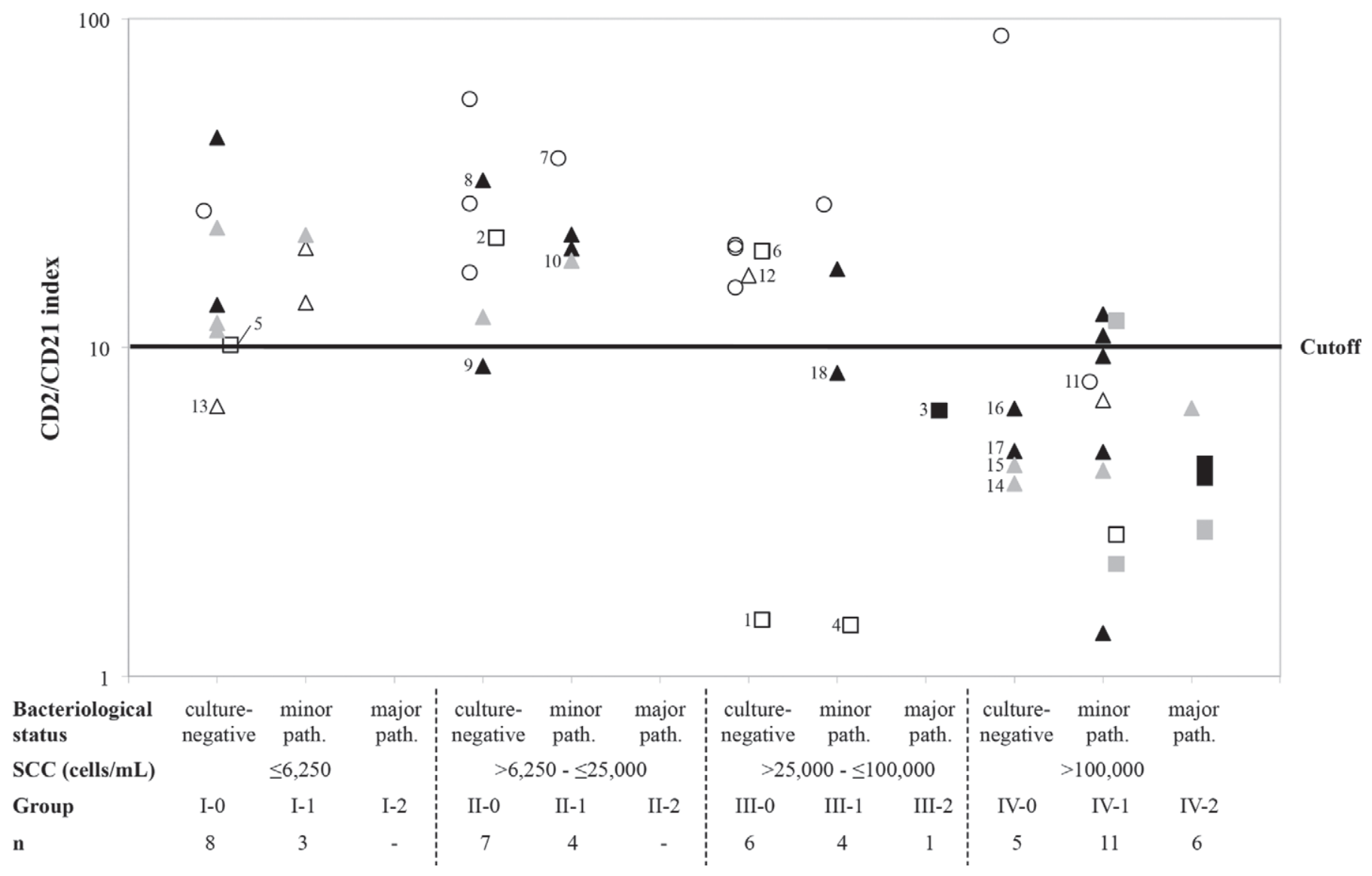

Figure 4. Associations between the proportion of $\mathrm{CD} 2{ }^{+}$lymphocytes per CD21 ${ }^{+}$lymphocytes (CD2/CD21 index) and cytobacteriological status of the 55 udder quarters in trial 2. The samples were classified into 4 SCC groups (group I: $\leq 6,250$ cells/mL; group II: $>6,250$ to $\leq 25,000$ cells/mL; group III: $>25,000$ to $\leq 100,000$ cells/mL; group IV: $>100,000$ cells/mL). Each group was subdivided into culture negative $(-0)$, minor pathogens $(-1)$, and major pathogens $(-2)$. To show the dynamics of the udder health status, the cytobacteriological status at the orientating base analysis and trial 1 is indicated by the following symbols: $\bigcirc=$ negative, $\Delta=$ minor pathogens at base analysis, $\square=$ major pathogens at base analysis, gray triangles $=$ minor pathogens in trial 1 , gray squares $=$ major pathogens in trial $2, \boldsymbol{\Delta}=$ minor pathogens at base analysis and in trial 1, $\mathbf{\square}=$ major pathogens at base analysis and in trial 1. Quarter numbers 1 to 18 are marked for additional analysis of differential cell counts, as their CD2/CD21 index differed from our working hypothesis ( $>10$ in unsuspicious quarters and $<10$ in microbiologically suspicious or diseased quarters) either in trial 1 or 2 . Each symbol represents the result of 1 udder quarter analyzed, but overlapping is possible. path. $=$ pathogens.

group II-0 (26) than in groups IV-1 (15) and IV-2 (7). However, the mean values in groups I-0 (19), III-0 (5), I-1 (19), II-1 (21), III-1 (10), III-2 (17), and IV-0 (21) did not differ significantly from any of the other groups.

Associations Between the CD2/CD21 Index and $\boldsymbol{D C C}$. All udder quarters analyzed in studies 1 and 2 were classified into 2 groups according to their CD2/CD21 indices $(>10$ or $<10)$. In total, 127 quarters indicated CD2/CD21 indices $>10$ (study $1, \mathrm{n}=70$; trial $1, \mathrm{n}=26$; trial $2, \mathrm{n}=31$ ). Values $<10$ were found in 71 quarters (study $1, \mathrm{n}=10$; trial $1, \mathrm{n}=37$; trial 2 , $\mathrm{n}=24)$.

In both studies, statistical analysis indicated significantly $(P<0.01)$ lower mean percentages of lymphocytes in quarters with CD2/CD21 indices $<10$ than in quarters with values $>10$ (Table 4 ). In case of macro- phages, the mean percentages indicated no significant differences depending on the CD2/CD21 index. Mean percentages of granulocytes were significantly $(P<$ 0.01 ) higher in quarters with $\mathrm{CD} 2 / \mathrm{CD} 21$ indices $<10$ than in quarters with values $>10$, confirming inflammatory processes based on the predominance of granulocytes (53-61\%) in quarters with CD2/CD21 indices $<10$.

\section{DISCUSSION}

The induction and suppression of immune responses is regulated by lymphocytes (Nickerson, 1989). They also play a significant role in the immunological processes of the bovine mammary gland (Sordillo et al., 1991; Shafer-Weaver et al., 1996), and were found 
Table 4. Comparison of differential cell counts in all quarter foremilk samples analyzed depending on the CD2/CD21 index (the proportion of $\mathrm{CD} 2^{+}$lymphocytes per CD21 $1^{+}$ymphocytes $)^{1}$

\begin{tabular}{|c|c|c|c|c|c|c|c|c|c|}
\hline \multirow[b]{2}{*}{ CD2/CD21 index } & \multicolumn{3}{|c|}{ Lymphocytes (\%) } & \multicolumn{3}{|c|}{ Macrophages (\%) } & \multicolumn{3}{|c|}{ Granulocytes (\%) } \\
\hline & $>10$ & $<10$ & $P$-value & $>10$ & $<10$ & $P$-value & $>10$ & $<10$ & $P$-value \\
\hline Trial $1(\mathrm{n}=63)$ & 55 & 36 & 0.004 & 12 & 11 & 0.60 & 33 & 53 & 0.002 \\
\hline Trial $2(\mathrm{n}=55)$ & 53 & 28 & 0.0042 & 16 & 12 & 0.09 & 31 & 60 & 0.0004 \\
\hline
\end{tabular}

${ }^{1}$ The udder quarters were classified into 2 groups: CD2/CD21 index $>10$ and CD2/CD21 index $<10$.

to be the predominant cell population in the milk of healthy udder quarters. Lymphocytes consist mainly of $\mathrm{T}$ cells, whereas $\mathrm{B}$ and NK cells are observed in low percentages (Outteridge and Lee, 1988; Lee et al., 1989). Research on the interaction of lymphocyte subpopulations revealed that $\mathrm{B}$ cells require the help of $\mathrm{T}$ cells to produce specific antibodies (Waldmann, 1979). The interaction of $\mathrm{T}$ and $\mathrm{B}$ lymphocytes in apparently healthy mammary glands with $\mathrm{SCC} \leq 100,000$ cells/mL remains poorly investigated. However, inflammatory reactions based on DCC analysis have already been found in that SCC range (Schwarz et al., 2010, 2011a,b; Pilla et al., 2012). In the current study, we predominantly analyzed the proportions of $\mathrm{CD} 2^{+} \mathrm{T}$ and $\mathrm{CD} 21^{+} \mathrm{B}$ lymphocytes purified from quarter foremilk samples with SCC $\leq 100,000$ cells/mL to improve knowledge of quantitative relationships between these lymphocyte populations in clinically healthy and subclinically infected bovine mammary glands, and to observe early changes in the immunological status of mammary glands.

Recent studies have indicated that calculated indices based on measured populations of cells in milk (e.g., logarithmic granulocyte:lymphocyte ratio) are suitable to aid differentiation between healthy and diseased udder quarters (Pilla et al., 2012, 2013; Rivas et al., 2013). In our experiments, a new variable - the CD2/CD21 index - was found empirically due to the significantly varying percentages of $\mathrm{CD} 2^{+} \mathrm{T}$ and $\mathrm{CD} 21^{+} \mathrm{B}$ lymphocytes in milk of apparently healthy $(\mathrm{SCC} \leq 100,000$ cells $/ \mathrm{mL}$ ) and diseased quarters (SCC $>100,000$ cells/ $\mathrm{mL})$. Percentages of $\mathrm{CD} 2^{+}$lymphocytes were notably high in milk samples showing SCC $\leq 100,000$ cells/ $\mathrm{mL}$ and culture-negative results. Information on CD2 ${ }^{+}$ lymphocytes under these conditions is not yet available in the literature. Only a mean proportion of $\mathrm{CD} 2^{+}$lymphocytes of $88 \%$, for healthy udder quarters defined by SCC $<450,000$ cells $/ \mathrm{mL}$, has been reported previously (Taylor et al., 1994). Results from 2 further studies showed that the mean proportion of $\mathrm{CD}^{+}$cells ranged from 83 to $85 \%$ in the milk of bacteriological negative udder quarters (Asai et al., 1998, 2000). However, SCC values were not presented. In contrast to the high percentages of $\mathrm{CD} 2^{+}$cells found in the milk of healthy quarters, the percentages were low in the milk of diseased quarters.

The CD $21^{+}$lymphocytes were detected in low percentages in samples showing SCC $\leq 100,000$ cells $/ \mathrm{mL}$ and culture-negative results. In a field study (Riollet et al., 2001), a mean proportion of CD $21^{+}$cells of $0.93 \%$ was found in the milk of 11 healthy cows with a SCC between 50,000 and 265,000 cells/mL. An experimental study (Mehrzad et al., 2008) also revealed a low mean proportion of $\mathrm{CD} 21^{+}$lymphocytes of $1 \%$ when analyzing milk of 6 cows with a mean SCC value of 53,000 cells/mL before inoculation with Escherichia coli.

Our results indicated that a CD2/CD21 index of 10 may be suitable to differentiate between unsuspicious and microbiologically suspicious or diseased udder quarters. Severely diseased quarters $(\mathrm{SCC}>100,000$ cells $/ \mathrm{mL}$ ) containing major pathogens generally revealed CD2/CD21 indices $<10$. In apparently healthy udder quarters (SCC $\leq 100,000$ cells/mL), the CD2/ CD21 index was generally $>10$. Thus, data highlighted a correlation between the CD2/CD21 index and the bacteriological status of the udder quarters, particularly when major pathogens were detected. To prove the assumption of whether a CD2/CD21 index $<10$ is primarily related to minor or major pathogens, a second biphasic study involving 2 trials was conducted. Quarters with $\mathrm{SCC} \leq 100,000$ cells/mL and $>100,000$ cells/ $\mathrm{mL}$, as well as with a different bacteriological status (culture negative, or minor or major pathogens), were chosen. Contrary to the low proportions of B lymphocytes in the milk of healthy udder quarters, our data indicated an increase of up to $45 \%$ in diseased quarters, confirming the results of previous studies (Riollet et al., 2001; Mehrzad et al., 2008). This increase in B lymphocytes suggests that a humoral immune response developed (Riollet et al., 2001). Data confirmed CD2/ CD21 indices $<10$ in severely diseased quarters with major pathogens (IV-2). Almost all quarters containing minor pathogens (IV-1) or culture-negative quarters (IV-0) with SCC $>100,000$ cells $/ \mathrm{mL}$ also revealed CD2/CD21 indices $<10$. However, in 7 of 36 quarters 
in group IV-1, CD2/CD21 indices $>10$ (10.87 to 19.93) were found and should be regarded as suspicious for minor or major pathogens. It is not clear whether the minor pathogens detected in these quarters originated from teat canal colonization or whether they caused an IMI (Devriese and De Keyser, 1980; Linde et al., 1980). The DCC data of 4 quarters (IV-1) supported an IMI, as proportions of granulocytes were 77 to $89 \%$, which is accepted as indicator for an inflammatory reaction (Pillai et al., 2001; Paape et al., 2002). The remaining 3 quarters did not indicate any inflammatory signs (granulocyte proportions 24 to $39 \%$ ). The high SCC may be influenced by noninfectious reasons, such as stress, stage of lactation, or age (Dohoo and Meek, 1982; Harmon, 1994).

Six quarters of group IV-0 showing CD2/CD21 indices $<10$ seemed to be bacteriologically false negative, as DCC data revealed inflammatory reactions based on the predominance of granulocytes (54-81\%). In addition, in these quarters, minor pathogens were detected in at least one previous analysis. Although quarters show a culture-negative result, they might be infected nonetheless. Negative bacteriological results could depend on intermittent shedding (Sears et al., 1990) and presence of antimicrobials or other inhibitors in milk (Reiter, 1978). Bacteria could also be ingested by phagocytes or survive intracellularly in the host at the time of sampling (Newbould and Neave, 1965; Hill et al., 1978). Shedding of too low amounts of the pathogens or ceased growth may be further reasons for negative bacteriological results (Sears et al., 1990).

In both trials of study 2, we also observed CD2/CD21 indices $<10$ in 15 of 64 samples with $\mathrm{SCC} \leq 100,000$ cells/mL, indicating inflammatory effects in apparently healthy udder quarters. Furthermore, all of these quarters revealed a current or previous detection of minor or major pathogens. The CD2/CD21 index of 8.69 for quarter no. 7 was the only real exception within the whole investigation, as DCC data showed no inflammation (granulocyte proportion 19\%) either. The reason for this could not be determined.

It can be stated that microbiologically suspicious CD2/CD21 indices $<10$ in almost all quarters and even in low-SCC milk can be explained by a current or former detection of minor or major pathogens, especially Staph. aureus, in the mammary gland. It has been established that Staph. aureus can occur at low SCC levels (Zecconi et al., 2005; Schwarz et al., 2010). However, in 6 to $10 \%$ (Piccinini et al., 2012) or even $40 \%$ (Sears et al., 1990) of the quarters infected with Staph. aureus, the microorganism was not detected in milk.

Bacteria here classified as minor pathogens include CNS (Reneau, 1986). Such a class comprises more than 10 different species (Pyörälä and Taponen, 2009), which differ in pathogenicity (Myllys, 1995; Aarestrup and Jensen, 1997). Regardless of taxonomic classifications, our data tend to differentiate between pathogenic $(\mathrm{CD} 2 / \mathrm{CD} 21$ index $<10)$ and inoffensive (CD2/CD21 index $>10)$ CNS species.

The statistical analysis of our experiments indicated that the farms had a significant effect on the percentages of $\mathrm{CD} 2^{+}$lymphocytes. This effect may be due to a nonrandomized selection of the cows within the farms and the different numbers of cows selected per farm. Whereas cows with healthy mammary glands were predominantly selected from farms A and C, samples from cows with diseased quarters were mainly collected from farm B. However, the CD2/CD21 index was not influenced statistically by the farm, or by the quarter position, lactation number, or DIM.

\section{CONCLUSIONS}

The CD2/CD21 index provides a trend for the characterization of udder health. Our examinations showed that values of $<10$ or $>10$ may be suitable to differentiate unsuspicious from microbiologically suspicious and diseased udder quarters. Therefore, quarters with CD2/ CD21 indices $<10$ should generally be seen as suspicious for minor or major pathogens. Together with the wellestablished SCC indicator, the CD2/CD21 index could represent a quick tool to provide reliable information about udder health status. It confirmed our working hypothesis in 171 of 198 quarters analyzed that values $>10$ were found in samples with $\mathrm{SCC} \leq 100,000$ cells $/ \mathrm{mL}$ and values $<10$ in samples with $\mathrm{SCC}>100,000$ cells/ $\mathrm{mL}$. In 26 of the remaining 27 quarters, CD2/CD21 indices $<10$ or $>10$ were explainable by the detection or absence of pathogens or DCC analysis. Because we performed field studies and, therefore, the stage of the infection in the individual udder quarters analyzed and the exact infection dynamics were unknown, specific longitudinal infection studies with major pathogens (e.g., Staph. aureus) and minor pathogens (e.g., CNS), respectively, are necessary to obtain a further understanding of the CD2/CD21 index.

\section{ACKNOWLEDGMENTS}

This work was funded by the Federal Ministry of Economics and Technology (Berlin, Germany) under support code KF2484201AJ9. The authors are grateful to Simone Urstadt (Department of Animal Sciences, Georg-August-University Göttingen, Göttingen, Germany) for her excellent technical assistance and to Lynne Armstrong (Languages: Interpreting and Translating, Edinburgh, UK) for critically reviewing 
the manuscript. Furthermore, we thank the four dairy farms for their cooperation.

\section{REFERENCES}

Aarestrup, F. M., and N. E. Jensen. 1997. Prevalence and duration of intramammary infections in Danish heifers during the peripartum period. J. Dairy Sci. 80:307-312.

Allison, J. P., and W. L. Havran. 1991. The immunobiology of T cells with invariant $\gamma \delta$ antigen receptors. Annu. Rev. Immunol. 9:679-705.

Asai, K., K. Kai, H. Rikiishi, S. Sugawara, Y. Maruyama, T. Yamaguchi, M. Ohta, and K. Kumagai. 1998. Variation in CD4 ${ }^{+} \mathrm{T}$ and $\mathrm{CD} 8^{+} \mathrm{T}$ lymphocyte subpopulations in bovine mammary gland secretions during lactating and non-lactating periods. Vet. Immunol. Immunopathol. 65:51-61.

Asai, K., Y. Komine, T. Kozutsumi, T. Yamaguchi, K. Komine, and K. Kumagai. 2000. Predominant subpopulations of T lymphocytes in the mammary gland secretions during lactation and intraepithelial $\mathrm{T}$ lymphocytes in the intestine of dairy cows. Vet. Immunol. Immunopathol. 73:233-240

Davis, W. C., W. C. Brown, M. J. Hamilton, C. R. Wyatt, J. A. Orden, A. M. Khalid, and J. Naessens. 1996. Analysis of monoclonal antibodies specific for the $\gamma \delta \mathrm{TcR}$. Vet. Immunol. Immunopathol. $52: 275-283$.

Davis, W. C., and G. S. Splitter. 1991. Individual antigens of cattle. Bovine CD2 (BoCD2). Vet. Immunol. Immunopathol. 27:43-50.

Devriese, L. A., and H. De Keyser. 1980. Prevalence of different species of coagulase-negative staphylococci on teats and in milk samples from dairy cows. J. Dairy Res. 47:155-158.

Dohoo, I. R., and A. H. Meek. 1982. Somatic cell counts in bovine milk. Can. Vet. J. 23:119-125.

Dosogne, H., F. Vangroenweghe, J. Mehrzad, A. M. Massart-Leën, and C. Burvenich. 2003. Differential leukocyte count method for bovine low somatic cell count milk. J. Dairy Sci. 86:828-834.

DVG (German Veterinary Society). 2000. Entnahme von Milchproben unter aseptischen Bedingungen. Sachverständigenausschuss "Subklinische Mastitis". DVG, Giessen, Germany.

DVG (German Veterinary Society). 2002. Leitlinien zur Bekämpfung der Mastitis als Bestandsproblem. Sachverständigenausschuss "Subklinische Mastitis". DVG, Giessen, Germany.

Faldyna, M., L. Leva, Z. Sladek, D. Rysanek, and M. Toman. 2006. $\gamma \delta$ - $\mathrm{TCR}^{+} \mathrm{CD}^{-}$lymphocytes are recruited into bovine mammary gland after stimulation. Vet. Med. (Praha) 51:258-264.

Harmon, R. J. 1994. Physiology of mastitis and factors affecting somatic cell counts. J. Dairy Sci. 77:2103-2112.

Hill, A. W., A. L. Shears, and K. G. Hibbitt. 1978. The elimination of serum-resistant Escherichia coli from experimentally infected single mammary glands of healthy cows. Res. Vet. Sci. 25:89-93.

IDF (International Dairy Federation). 1981. Laboratory methods for use in mastitis work. Document 132. IDF, Brussels, Belgium.

Jain, N. C. 1979. Common mammary pathogens and factors in infection and mastitis. J. Dairy Sci. 62:128-134.

Lee, C. S., E. Meeusen, and M. R. Brandon. 1989. Subpopulations of lymphocytes in the mammary gland of sheep. Immunology 66:388-393.

Linde, C., O. Holmberg, and G. Aström. 1980. The interference between coagulase-negative staphylococci and Corynebacterium bovis and the common udder pathogens in the lactating cow. Nord. Vet. Med. 32:552-558.

Mehrzad, J., D. Janssen, L. Duchateau, and C. Burvenich. 2008. Increase in Escherichia coli inoculum dose accelerates CD8 ${ }^{+}$T-cell trafficking in the primiparous bovine mammary gland. J. Dairy Sci. 91:193-201.

Myllys, V. 1995. Staphylococci in heifer mastitis before and after parturition. J. Dairy Res. 62:51-60.

Newbould, F. H. S., and F. K. Neave. 1965. The recovery of small numbers of Staphylococcus aureus infused into the bovine teat cistern. J. Dairy Res. 32:157-162.
Nickerson, S. C. 1989. Immunological aspects of mammary involution. J. Dairy Sci. 72:1665-1678

Outteridge, P. M., and C. S. Lee. 1988. The defense mechanisms of the mammary gland of domestic ruminants. Prog. Vet. Microbiol. Immunol. 4:165-196.

Oviedo-Boyso, J., J. J. Valdez-Alarcón, M. Cajero-Juárez, A. OchoaZarzosa, J. E. López-Meza, A. Bravo-Patiño, and V. M. Baizabal-Aguirre. 2007. Innate immune response of bovine mammary gland to pathogenic bacteria responsible for mastitis. J. Infect. 54:399-409.

Paape, M. J. Mehrzad, X. Zhao, J. Detilleux, and C. Burvenich. 2002. Defense of the bovine mammary gland by polymorphonuclear neutrophil leukocytes. J. Mammary Gland Biol. Neoplasia 7:109-121.

Park, Y. H., L. K. Fox, M. J. Hamilton, and W. C. Davis. 1993 Suppression of proliferative response of BoCD4+ T lymphocytes by activated $\mathrm{BoCD} 8^{+} \mathrm{T}$ lymphocytes in the mammary gland of cows with Staphylococcus aureus mastitis. Vet. Immunol. Immunopathol. 36:137-151.

Piccinini, R., R. Tassi, V. Daprà, R. Pilla, J. Fenner, B. Carter, and M. F. Anjum. 2012. Study of Staphylococcus aureus collected at slaughter from dairy cows with chronic mastitis. J. Dairy Res. 79:249-255.

Pilla, R., M. Malvisi, G. G. M. Snel, D. Schwarz, S. König, C.-P. Czerny, and R. Piccinini. 2013. Differential cell count as an alternative method to diagnose dairy cow mastitis. J. Dairy Sci. 96:1653-1660.

Pilla, R., D. Schwarz, S. König, and R. Piccinini. 2012. Microscopic differential cell counting to identify inflammatory reactions in dairy cow quarter milk samples. J. Dairy Sci. 95:4410-4420.

Pillai, S. R., E. Kunze, L. M. Sordillo, and B. M. Jayarao. 2001. Application of differential inflammatory cell count as a tool to monitor udder health. J. Dairy Sci. 84:1413-1420.

Pyörälä, S., and S. Taponen. 2009. Coagulase-negative staphylococciEmerging mastitis pathogens. Vet. Microbiol. 134:3-8.

Reiter, B. 1978. Review of progress of dairy science - Anti-microbial systems in milk. J. Dairy Res. 45:131-147.

Reneau, J. K. 1986. Effective use of dairy herd improvement somatic cell counts in mastitis control. J. Dairy Sci. 69:1708-1720.

Reneau, J. K., and V. L. Packard. 1991. Monitoring mastitis, milk quality and economic losses in dairy fields. Dairy Food Environ. Sanit. 11:4-11.

Riollet, C., P. Rainard, and B. Poutrel. 2001. Cell subpopulations and cytokine expression in cow milk in response to chronic Staphylococcus aureus infection. J. Dairy Sci. 84:1077-1084.

Rivas, A. L., M. Jankowski, R. Piccinini, G. Leitner, D. Schwarz, K. L. Anderson, J. M. Fair, A. L. Hoogesteijn, W. Wolter, M. Chaffer, S. Blum, T. Were, S. N. Konah, P. Kempaiah, J. M. Ong'echa, U. S. Diesterbeck, R. Pilla, C.-P. Czerny, J. B. Hittner, J. M. Hyman, and D. J. Perkins. 2013. Feedback-based, system-level properties of vertebrate-microbial interactions. PLoS ONE 8:e53984.

Rivas, A. L., F. W. Quimby, J. Blue, and O. Coksaygan. 2001. Longitudinal evaluation of bovine mammary gland health status by somatic cell counting, flow cytometry, and cytology. J. Vet. Diagn. Invest. 13:399-407.

Rivas, A. L., S. J. Schwager, R. N. González, F. W. Quimby, and K. L. Anderson. 2007. Multifactorial relationships between intramammary invasion by Staphylococcus aureus and bovine leukocyte markers. Can. J. Vet. Res. 71:135-144.

Rivas, A. L., R. Tadevosyan, F. W. Quimby, and D. H. Lein. 2002. Blood and milk cellular immune responses of mastitic non-periparturient cows inoculated with Staphylococcus aureus. Can. J. Vet. Res. 66:125-131.

Schwarz, D., U. S. Diesterbeck, K. Failing, S. König, K. Brügemann, M. Zschöck, W. Wolter, and C.-P. Czerny. 2010. Somatic cell counts and bacteriological status in quarter foremilk samples of cows in Hesse, Germany-A longitudinal study. J. Dairy Sci. 93:5716-5728.

Schwarz, D., U. S. Diesterbeck, S. König, K. Brügemann, K. Schlez, M. Zschöck, W. Wolter, and C.-P. Czerny. 2011a. Microscopic differential cell counts in milk for the evaluation of inflammatory 
reactions in clinically healthy and subclinically infected bovine mammary glands. J. Dairy Res. 78:448-455.

Schwarz, D., U. S. Diesterbeck, S. König, K. Brügemann, K. Schlez, M. Zschöck, W. Wolter, and C.-P. Czerny. 2011b. Flow cytometric differential cell counts in milk for the evaluation of inflammatory reactions in clinically healthy and subclinically infected bovine mammary glands. J. Dairy Sci. 94:5033-5044.

Sears, P. M., B. S. Smith, P. B. English, P. S. Herer, and R. N. Gonzalez. 1990. Shedding pattern of Staphylococcus aureus from bovine intramammary infections. J. Dairy Sci. 73:2785-2789.

Seegers, H., C. Fourichon, and F. Beaudeau. 2003. Production effects related to mastitis and mastitis economics in dairy cattle herds. Vet. Res. 34:475-491.

Shafer-Weaver, K. A., G. M. Pighetti, and L. M. Sordillo. 1996. Diminished mammary gland lymphocyte functions parallel shifts in trafficking patterns during the postpartum period. Proc. Soc. Exp. Biol. Med. 212:271-280.

Sopp, P. 1996. Ruminant cluster CD21. Vet. Immunol. Immunopathol. 52:249.

Sordillo, L. M., M. Campos, and L. A. Babiuk. 1991. Antibacterial activity of bovine mammary gland lymphocytes following treatment with interleukin-2. J. Dairy Sci. 74:3370-3375.
Sordillo, L. M., and S. C. Nickerson. 1988. Morphometric changes in the bovine mammary gland during involution and lactogenesis. Am. J. Vet. Res. 49:1112-1120.

Sordillo, L. M., and K. L. Streicher. 2002. Mammary gland immunity and mastitis susceptibility. J. Mammary Gland Biol. Neoplasia $7: 135-146$.

Taylor, B. C., J. D. Dellinger, J. S. Cullor, and J. L. Stott. 1994. Bovine milk lymphocytes display the phenotype of memory $\mathrm{T}$ cells and are predominantly $\mathrm{CD}^{+}$. Cell. Immunol. 156:245-253.

Viguier, C., S. Arora, N. Gilmartin, K. Welbeck, and R. O'Kennedy. 2009. Mastitis detection: Current trends and future perspectives. Trends Biotechnol. 27:486-493.

Waldmann, H. 1979. Interactions between T and B cells: A review. J. R. Soc. Med. 72:198-202.

Zecconi, A., E. Binda, V. Borromeo, and R. Piccinini. 2005. Relationship between some Staphylococcus aureus pathogenic factors and growth rates and somatic cell counts. J. Dairy Res. 72:203-208. 